\title{
PENGEMBANGAN UNIT USAHA IbKIK-INFORMASI GEOSPASIAL MELALUI JASA PELATIHAN DAN PEKERJAAN INFORMASI GEOSPASIAL
}

\author{
T.B. Kusmiyarti ${ }^{1}$, R. Suyarto ${ }^{2}$, I K. Sardiana ${ }^{3}$, dan P. P. K. Wiguna ${ }^{2}$
}

\begin{abstract}
ABSTRAK
Peningkatan kebutuhan informasi geospasial dan SDM yang memiliki kompetensi di bidang informasi geospasial merupakan peluang usaha yang sangat menjanjikan. Bermitra dengan PPIDS Universitas Udayana, unit usaha IbKIK_Informasi Geospasial mulai dirintis pembentukannya. Tulisan ini bertujuan untuk mengkaji proses dan hasil kegiatan usaha yang telah dilakukan oleh unit IbKIK-Informasi Geospasial. Hasil kajian menunjukkan unit usaha telah berjalan dengan baik. Selama kurun waktu 2017-2018 telah menjual produk yang berupa jasa pelatihan informasi geospasial sebanyak 9 kegiatan dan jasa pekerjaan informasi geospasial sebanyak 7 kegiatan. Produk lain yang telah dirintis adalah menjalin kerjasama dengan LSP-Geospasial untuk melakukan Uji Kompetensi. Unit Usaha ini juga merupakan pusat bagi pengembangan kompetensi mahasiswa dan alumni dalam bidang informasi geospasial.
\end{abstract}

Kata kunci : informasi geospasial, unit usaha, jasa, kompetensi

\begin{abstract}
Increasing the need for geospatial information and human resources that have competence in the field of geospatial information is a very promising business opportunity. Partnering with PPIDS, Udayana University, IbKIK_ business unit Geospatial information was initiated by its formation. This paper aims to examine the process and results of business activities that have been carried out by the IbKIK-Geospatial Information unit. The results of the study show that the business unit is running well. During the 2017-2018 period, 9 products were sold in the form of geospatial information training services and 7 geospatial information services. Another product that has been initiated is collaborating with the Geospatial LSP to conduct a Competency Test. This Business Unit is also a center for developing the competencies of students and alumni in the field of geospatial information.
\end{abstract}

Keywords: geospasil, information, busines unit, service, competence

\section{PENDAHULUAN}

Dengan diberlakukannya UU No. 4 Tahun 2011 tentang Informasi Geospasial, PerPres No. 9 Tahun 2006 tentang Kebijakan Satu Peta (KSP), demikian juga dengan diterapkannya UU Desa, maka kebutuhan tentang data dan informasi geospasial saat ini menjadi sangat penting. Berdasarkan undang-undang dan peraturan tersebut secara umum pembangunan saat ini harus

${ }^{1}$ Staf Pengajar Prodi Agroekoteknologi, Fak. Pertanian, Universitas Udayana,: tatihartanto@ymail.com. ${ }^{2}$ Staf Pengajar Prodi Agroekoteknologi, Fakultas Pertanian Universitas Udayana, rsuyarto@yahoo.co.id

${ }^{3}$ Staf Pengajar Prodi Agroekoteknologi Fakultas Pertanian UniversitasUdayana, ksardiana@yahoo.co.id

${ }^{4}$ Staf Pengajar Prodi Agroekoteknologi Fakultas Pertanian Universitas Udayana, putu.perdana@gmail.com 
didasari oleh adanya peta yang valid dan benar mulai dari tingkat desa, kabupaten/kota, provinsi hingga Negara Kesatuan republik Indonesia. Kebijakan Satu Peta merupakan arahan strategis dalam terpenuhinya satu peta yang mengacu pada satu referensi, satu standar, satu basisdata dan satu geoportal (UU No. 9 Tahun 20016, ps 1). Pelaksanaan KSP berfungsi sebagai acuan perbaikan data informasi geospasial tematik (IGT) per sektor dan acuan perencanan pemanfaatan (UU No.9 Tahun 2016, ps 2). KSP merupakan gerakan pembangunan informasi geospasial secara partisipatif dan kolaboratif antar sektor/lembaga di tingkat desa hingga Negara menuju satu referensi, satu standar, satu basisdata dan satu geoportal (Nurwajedi, 2016).

Di tingkat desa, terkait dengan UU Desa, informasi geospasial tematik perdesaan berperan sebagai instrument untuk menyelesaikan permasalahan sosial dalam menuju desa mandiri. Kebutuhan pemetaan tematik dalam konteks desa membangun bertujuan untuk menyiapkan dataset tematik berbasis pedesaan untuk memfasilitasi desa dalam menyusun rencana pembangunan. Peta Desa sangat berperan untuk: 1) mengetahui posisi dalam konteks regional, 2) mengetahui aspek potensi: produksi, distribusi dan fungsionalitas kawasan desa, 3) membantu dalam mempertegas wilayah, 4) inventarisasi asset desa dan pengelolaan BUMDes, 5) membantu perencanaan pembangunan infrastruktur desa dan kawasan pedesaan dan 6) peta desa sebagai dasar informasi untuk integrasi spasial pembanguan wilayah (Marfai, 2016). Sementara untuk Bali, peta desa juga memiliki arti strategis dalam penglolaan desa adat peta desa adat di Bali memiliki arti penting dalam pengelolaan desa adat sehingga ketersediaan peta desa adat menjadi kebutuhan yang mendasar. (Sardiana dan Windia, 2018)

Dengan demikian, ketersediaan informasi geospasial yang akurat dan terpercaya dan juga tenagatenaga profesional dalam bidang informasi geospasial saat ini sangat diperlukan untuk menunjang pembangunan baik di tingkat desa sampai ke tingkat Negara Kesatuan Republic Indonesia dari perencanaan hingga proses pengambilan keputusan (Baja, 2012). Meningkatnya kebutuhan informasi geospasial akan mendorong meningkatnya kebutuhan sumberdaya manusia mahir di bidang informasi geospasial. Secara nasional, kebutuhan sumberdaya manusia mencapai kisaran 50.000 orang (Abidin, 2017).

Terbukanya peluang untuk membantu dalam memenuhi kebutuhan SDM informasi geospasial yang begitu luas, dengan PPIDS Universitas Udayana sebagai mitra maka melalui bantuan dana hibah dari Dikti dirintis pembentukan unit usaha IbKIK-Informasi Geospasial sejak tahun 2017. Sumberdaya yang tersedia di PPIDS Unud, baik SDM maupun perangkat penunjang yang ada sangat memadaidan dapat menunjang unit usaha ini. Unit usaha yang dibentuk dimaksudkan sebagai wahana untuk memacu dan mengembangkan jiwa entrepreneurship di kalangan sivitas akademika, dan sekaligus sebagai tempat perolehan pendapatan mandiri atau bermitra melalui komersialisasi hasil-hasil inovasi intelektual kampus utamanya di bidang informasi geospasial.

Tujuan dari tulisan ini adalah mengkaji proses dan hasil pengembangan unit usaha IbKIKInformasi Geospasial di Universitas Udayana sebagai sarana sivitas akademika untuk komersialisasi produk-produk inovasi intelektual kampus, dan juga perannya dalam memberikan pelayanan kepada masyarakat baik dosen, mahasiswa, alumni, suasta ataupun pemerintah daerah, terutama yang berkaitan dengan data dan informasi geospasial

\section{METODE PELAKSANAAN}

Unit usaha IbKIK-Informasi Geospasial merupakan lembaga yang berada di bawah tanggungjawab Rektor Universitas Udayana dan didirikan dengan SK Rektor No. 1012/UN14/PM/2017 dengan 
mitra Pusat Pengembangan Infrastruktur Data Spasial (PPIDS) Universitas Udayana sebagai pembina sekaligus penyedia data dan informasi geospasial. Produk unit usaha ini berupa jasa pelatihan informasi geospasial dan jasa pekerjaan informasi geospasial. Berikut ini adalah spesifikasi produk dan metode yang dilakukan dalam proses penjualan produk:

A. Waktu Pelaksanaan Kegiatan:

Waktu pelaksanakan jasa pelatihan disesuaikan dengan jadwal pelatihan yang ditawarkan secara berkala atau menurut permintaan konsumen. Sedangkan waktu pelaksanaan jasa pekerjaan informasi geospasial disesuaikan berdasarkan kesepakatan pengguna.

B. Tempat pelaksanaan Kegiatan:

Pelatihan dilakukan baik di lingkungan unit Usaha IbKIK-Informasi Geospasial di Gedung Agrokomplek Lt. 4 Universitas Udayana Kampus Sudirman maupun di instansi pemerintah yang memerlukan pembinaan.

C. Pelaksanaan Kegiatan:

Kegiatan peningkatan kompetensi bidang informasi geospasial dilakukan melalui pelatihan-pelatihan. Pelatihan dilakukan dengan berbagai metode, yaitu:

1. Pelatihan dengan sistem berbayar melalui penawaran-penawaran program dan jenis materi pelatihan. Terdapat 3 tingkatan pelatihan untuk masing-masing jenis materi pelatihan, yaitu tingkat dasar, tingkat lanjut dan tingkat mahir. Sedangkan pilihan materi pelatihan yang disediakan adalah Sistem Informasi Geografis (SIG), Penginderaan Jauh (Remote Sensing), Kartografi dan Hidrografi.

2. Pelatihan yang dilakukan sebagai bagian tak terpisahkan dari pekerjaan jasa informasi geospasial. Program pelatihan melalui metode ini dilakukan guna memberikan pendampingan untuk pemanfaatan sistem informasi geografi yang dihasilkan serta proses updating dan pemeliharaan data dari hasil pekerjaan jasa informasi geospasial. Pekerjaan jasa informasi geospasial umumnya berasal dari instansi pemerintah seperti dinas PU, dinas Pertanian, BAPPEDA, Tapem dan lain-lain, sehingga pelatihan dan pembinaan diberikan kepada staf instansi yang bertanggungjawab terhadap data dan sistem informasi geospasial tematik yang dihasilkan.

3. Memberikan jasa konsultasi bagi pemerintah daerah melalui asistensi dan supervisi dalam penyusunan peta tata ruang. Jasa ini diberikan untuk membantu pemerintah daerah dalam menyiapkan peta yang benar dan sesuai dengan ketentuan-ketentuan teknis dalam penyusunan peta menurut undang-undang dan peraturan pemerintah RI.

4. Pelatihan peningkatan kompetensi di bidang informasi geospasial yang dilakukan dengan system tanpa bayar. Kegiatan ini biasanya diberikan kepada mahasiswa dan dosen baik yang dilakukan secara berkala maupun dilakukan atas kerjasama dengan berbagai instansi pemerintah atau suasta, seperti yang telah dilakukan atas kerjasama dengan BIG, BPBD, BNPB, ESRI Indonesia, HOT-OpenStreetMap, dan SuperMap-China.

5. Pelatihan Survei untuk memperoleh data dan Pengolahan Data Informasi Geografi bagi mahasiswa dan alumni. Kegiatan ini ditawarkan bagi mahasiswa atau alumni yang ingin memperdalam kemampuannya secara langsung di Unit Usaha IbKIK-IG Universitas Udayana sekaligus memperoleh pengetahuan tentang teknologi praktis dan terbaru dalam bidang informasi geospasial yang umumnya belum diperoleh dalam kegiatan pembelajaran di kelas. Kegiatan ini biasanya ditawarkan kepada mahasiswa dan alumni berkaitan dengan pekerjaan jasa informasi geospasial.

Untuk penjualan jasa pekerjaan informasi geospasial, yang umumnya merupakan hasil kerjasama dengan berbagai instansi pemerintah, langkah-langkah yang dilakukan diawali dengan penandatanganan SPK tentang isi pekerjaan, diikuti dengan pelaksanaan pekerjaan dan diakhiri dengan penyusunan dan penyerahan laporan dan hasil pekerjaan. Pelaksanaan pekerjaan umumnya 
diawali dengan penggalian data informasi dengan melakukan survai terhadap data informasi yang berreferensi geografi.

\section{HASIL DAN PEMBAHASAN}

Unit usaha IbKIK-Informasi Geospasial yang dirintis pendiriannya sejak tahun 2017 telah melakukan berbagai kegiatan pengembangan baik dari aspek produksi, manajemen, promosi, penjualan produk serta investasi sarana dan prasarana. Dalam tahun 2017-2018 telah dilakukan sebanyak 9 kali penjualan jasa pelatihan dengan berbagai bentuk pelatihan dan 7 pekerjaan jasa informasi geospasial dari berbagai instansi pemerintah. Berdasarkan kuisioner yang dibagikan pada setiap pelaksanaan kegiatan, maka diperoleh berbagai tanggapan atas layanan yang disediakan dan diberikan oleh Unit Usaha IbKIK-Informasi Geospasial Universitas Udayana, diantaranya:

1. Pengguna jasa pelatihan terdiri dari mahasiswa, alumni, dosen, pegawai suasta maupun pegawai pemerintah.

2. Sebanyak $64 \%$ pengguna jasa pelatihan berkeinginan untuk melanjutkan pelatihan ke tingkat yang lebih tinggi.

3. Sebanyak $89 \%$ pengguna jasa pelatihan menyatakan bahwa layanan pelatihan tentang data dan informasi geospasial sangat diperlukan dalam mendukung berbagai kegiatan pengguna baik penelitian (dosen, mahasiswa) maupun dalam upaya melengkapi, mengolah dan memanfaatkan berbagai data dan informasi geospasial daerah

4. Sebanyak $97 \%$ pengguna jasa pekerjaan informasi geospasial menyatakan bahwa data dan informasi geospasial yang berupa sistem informasi geografi (SIG) sangat mendukung proses pengambilan keputusan dalam pembangunan.

5. Sebanyak $43 \%$ pengguna pelatihan menginginkan untuk diadakan Uji Kompetensi.

Dari hasil pengkajian terhadap berbagai kegiatan yang dilakukan oleh Unit Usaha IbKIK-Informasi Geospasial Universitas Udayana melalui penyebaran kuisioner terhadap pengguna layanan yang disediakan secara umum menunjukkan bahwa keberadaan unit usaha ini selain merupakan wahana income generating, penumbuhan jiwa entrepreneurship bagi sivitas akademika di Universitas Udayana sebagai institusi pendidikan tinggi, juga dapat menjadi pusat pengembangan diri bagi mahasiswa dan alumni untuk memperkaya pengalaman dan pengetahuan tentang arti penting data dan informasi geospasial dalam pengembangan ilmu maupun kemanfaatannya sekaligus memberikan kemudahan bagi pengguna untuk mendapatkan data dan informasi geospasial.

Untuk mendukung kegiatan pelatihan yang dilakukan di Unit Usaha IbKIK-Informasi Geospasial, maka penjajagan untuk menjalin kerjasama dengan LSP Geospasial dan BNSP agar dapat melakukan uji kompetensi di wilayah Bali sedang dilakukan. Sertifikat kompetensi yang akan diperoleh dalam uji kompetensi ini dapat menjadi bekal positif bagi pemiliknya.

Hasil kajian terdahulu melalui pengolahan matrik internal dan eksternal dengan metode SWOT, Unit Usaha IbKIK-Informasi Geospasial Universitas Udayana, maka unit usaha IbKIKInformasi Geospasial Universitas Udayana berada pada posisi sel 4, yang diperoleh dari nilai EFI sebesar 3,01 yang menunjukkan posisi unit usaha kuat, sedangkan nilai EFE 2,44 yang berarti posisi eksternalnya sedang. Dengan demikian strategi yang harus diterapkan adalah strategi stability dan berhati-hati terhadap faktor internal maupun eksternal (Kusmiyarti, dkk., 2019). 


\section{KESIMPULAN DAN SARAN}

\subsection{Kesimpulan}

Dari hasil kajian terhadap proses dan hasil pengembangan yang dilakukan oleh unit usaha IbKIK-Informasi Geospasial dapat disimpulkan bahwa:

1. Unit usaha IbKIK-Informasi Geospasial telah berjalan dengan baik ditinjau dari manajemen, SDM pendukung, sarana dan prasarana serta produk yang ditawarkan.

2. Produk yang ditawarkan memiliki peminat yang sangat luas.

3. Usaha yang dijalankan telah menghasilkan profit, selama 2 tahun penyelenggaraannya (2017-2018) telah menjual 9 kegiatan pelatihan dan 7 jasa pekerjaan informasi geospasial.

4. Pengembangan lebih lanjut berupa uji kompetensi telah dilakukan dengan menjalin kerjasama dengan lembaga sertifikasi (LSP Geospasial) untuk memenuhi permintaan pengguna.

\subsection{Saran}

Perlu dilakukan promosi secara lebih luas dan lebih sering agar kerjasama dengan instansi semakin luas.

\section{UCAPAN TERIMAKASIH}

Ucapan terima kasih disampaikan kepada Direktorat Riset dan Pengabdian Masyarakat Kemenristek atas bantuan pendanaan kegiatan P2UPIK melalui Lembaga Penelitian dan Pengabdian kepada Masyarakat (LPPM) Universitas Udayana dan Rektor Universitas Udayana atas segala fasilitas yang disediakan untuk menunjang kegiatan PPUPIK Informasi geospasial.

\section{DAFTAR PUSTAKA}

Abidin, Z.A.2017. Human Resource Development Geospatial information for national development needs and facing global challenges. Annual Scientific Forum 2017. Indonesian Surveyor Association. Pekanbaru.

Baja, S. 2012. Perencanaan Tata Guna Lahan dalam Pengembangan Wilayah. Pendekatan Spasial dan Aplikasinya. Yogyakarta. Penerbit Andi.

Sardiana, I.K., D Susila, AA Supadma, M Saifulloh. 2017. Soil Fertility Evaluation and Land Management of Dryland Farming at Tegallalang Sub-District, Gianyar Regency, Bali, Indonesia IOP Conf. Ser.: Earth Environ. Sci.98012043

Sardiana, I.K., IWP Windia . 2018. Pemetaan Partisipatif melalui Aplikasi GPS untuk Mitigasi Konflik Batas Wilayah: Studi Kasus di Desa Adat Nyuh Kuning, Ubud, Bali. Journal of Bali Studie. Volume 8 no. 1. Hal 145-158.

Marfai, A. 2016. Pentingnya Peta Desa dalam Percepatan Pembangunan Desa. Makalah disampaikan dalam Seminar Nasional Peta Desa untuk Percepatan Pembangunan Desa dan Kawasan Perdesaan. University Club. UGM. Yogyakarta. 24 Februaru 2016.

Nurwadjedi. 2016. Kebutuhan Penyelenggaraan IGT Perdesaan. Makalah disampaikan dalam Seminar Nasional Peta Desa untuk Percepatan Pembangunan Desa dan Kawasan Perdesaan. University Club. UGM. Yogyakarta. 24 Februaru 2016. 